\title{
Testicular Germ Cell Neoplasia In Situ
}

National Cancer Institute

\section{Source}

National Cancer Institute. Testicular Germ Cell Neoplasia In Situ. NCI Thesaurus. Code C40345.

A non-invasive lesion of the testis, characterized by the presence of malignant large germ cells with abundant cytoplasm in the seminiferous tubules. It may be associated with undescended or atrophic testis and infertility. The vast majority of cases progress to invasive germ cell tumors. 